\title{
Modulation of Salt Stress Induced Responses in Pea (Pisum sativum L.) Through Salicylic Acid and Trichoderma Application
}

\author{
Ajay Kumar Singh and Padmanabh Dwivedi* \\ Department of Plant Physiology, Institute of Agricultural Sciences, Banaras Hindu University, \\ Varanasi-221005, India \\ *Corresponding author
}

\section{A B S T R A C T}

\section{Keywords}

Antioxidative enzymes,

Salicylic acid, Salinity,

Superoxide radical,

Trichoderma asperellum

$\mathrm{T} 42$

Article Info

Accepted:

26 March 2018

Available Online:

10 April 2018

Salinity Stress is one of the most important abiotic stresses that cause adverse effects on crop productivity and agricultural sustainability. The present experiment was carried out as a pot-culture in the poly-house on pea genotype HUP-2 under salinity stress, and identified various biochemical attributes which were progressively reduced with increase in salinity level due to formation of reactive oxygen species i.e. hydrogen peroxide $\left(\mathrm{H}_{2} \mathrm{O}_{2}\right)$ and superoxide radical $\left(\mathrm{O}_{2}{ }^{-*}\right)$. Treatment of seeds with Trichoderma asperellum (T42) and exogenous application of salicylic acid, solitary or in combination, ameliorated salt stress induced responses as reflected by detoxification of both reactive oxygen species, $\mathrm{H}_{2} \mathrm{O}_{2}$ and $\mathrm{O}_{2}{ }^{--}$and also observed reduction in lipid peroxidation by enhancement of osmoprotectants i.e. proline content and activation of antioxidative enzymes activity like superoxide dismutase and ascorbate peroxidase as compared to control of respective salinity levels (4, 8 and $\left.12 \mathrm{dSm}^{-1}\right)$. Exogenous foliar application of SA $(0.25 \mathrm{mM})$, singly and in combination of Trichoderma, ameliorated the hostile effects of salinity up to the level of 8 $\mathrm{dSm}^{-1}$ which showed a significant expansion of plant phenotype as compared to the untreated stressed plants.

\section{Introduction}

Pulse production is greatly reduced due to the sensitivity of the plants to biotic and abiotic stresses. Pea (Pisum sativum L.) is the most important and globally known cool season legume vegetable crop belonging to Fabaceae family having important nutritional value i.e. high protein, carbohydrates, phosphorus, iron, calcium and vitamins content (Nutrition Facts: Peas, 2015). It is grown in many soil types, but performs better in fertile, light-textured, well-drained sandy loam soil (Hartmann et al.,
1988; Elzebroek and Wind, 2008). It is very sensitive to soil salinity which affects the plant growth and development leading to a pronounced decrease of biomass production and overall detrimental impact on pea productivity. Soil salinization is a serious threat to crop productivity and predicted to increase in the face of global climate change (FAO, 2011). Salinity is a major environmental factor adversely affecting crop production and agricultural sustainability in many regions of the world as it reduces the value and productivity of the affected land 
(Tejera et al., 2007; Qadir et al., 2008; Flowers et al., 2010).

Salicylic acid (SA) is a crucial endogenous naturally occurring plant produced phenolic compound that modulates plant responses to various biotic and abiotic stresses. As a signalling molecule, several researches have well investigated the significant role of SA in the regulation of defense mechanism of plants to many abiotic stresses (Gautam and Singh 2009; Simaei et al., 2011; Ying et al., 2013). SA accumulated in the plant tissues under unfavourable environmental conditions and contributes to increase of plant's tolerance to salinization (Syeed et al., 2011; Liu et al., 2014). Exogenous application of SA has been reported to influence a widespread of morphophysiological and biochemical parameters of plants under salinity stress, including plant growth and development, mineral uptake and transport, ion balance, stomatal conductance, transpiration, photosynthetic parameters, lipid peroxidation, anti-oxidative enzyme activities, metabolite accumulation, etc. (Gautam and Singh 2009; Syeed et al., 2011; Sharma et al., 2012; Bastam et al., 2013; Liu et al., 2014).

Trichoderma is a fungal genus found in many ecosystems and plays an important role in biological control of soil borne pathogens. It can reduce the severity of plant diseases by inhibiting plant pathogens in the soil through their highly potent antagonistic and mycoparasitic activity (Harman and Kubicek, 1998).

There are evidences from the experimental findings that some strains of Trichoderma interact with roots, enhancing plant growth potentials and resistance to biotic and tolerance to abiotic stresses (Howell, 2003; Hermosa et al., 2012). Trichoderma rhizosphere-competent strains have been shown to have direct effects on plants, increasing their growth potential, nutrient uptake, fertilizer use efficiency, rate of seed germination and stimulation of plant defensee against biotic and abiotic damages (Shoresh $e t$ al., 2010). Keeping this in mind, the present study on the effect of salinity on various morphological and biochemical attributes, along with ameliorating effects of salicylic acid and Trichoderma over salinity stress was investigated.

\section{Materials and Methods}

\section{Experimental details}

The present experiment was carried out as pot culture in the poly house and the Laboratory of Stress Physiology in the Department of Plant Physiology, Institute of Agricultural Sciences, Banaras Hindu University, Varanasi, Uttar Pradesh, India. Disease free and healthy seeds of pea (Pisum sativum L.) genotype (HUP-2) and fungal bio-control agent Trichoderma asperellum (T42) were obtained from the Department of Genetics and Plant Breeding and Department of Mycology and Plant Pathology, Institute of Agricultural Sciences, Banaras Hindu University, Varanasi, respectively. The experiment was laid out in Complete Randomized Design (CRD) which consisted of 13 treatments, 3 replications for each treatment. The data were obtained at different growth periods of 40, 60 and 80 days after sowing (DAS).

\section{Treatment details}

Thirteen treatments included $\mathrm{T} 0=$ Control, $\mathrm{T} 1$ $=\mathrm{NaCl}\left(4 \mathrm{dSm}^{-1}\right), \mathrm{T} 2=\mathrm{NaCl}\left(4 \mathrm{dSm}^{-1}\right)+\mathrm{SA}$ $(0.25 \mathrm{mM}), \mathrm{T} 3=\mathrm{NaCl}\left(4 \mathrm{dSm}^{-1}\right)+T$. asperellum $\mathrm{T} 42, \mathrm{~T} 4=\mathrm{NaCl}\left(4 \mathrm{dSm}^{-1}\right)+\mathrm{SA}$ $(0.25 \mathrm{mM})+$ T. asperellum $\mathrm{T} 42, \mathrm{~T} 5=\mathrm{NaCl}(8$ $\left.\mathrm{dSm}^{-1}\right), \mathrm{T} 6=\mathrm{NaCl}\left(8 \mathrm{dSm}^{-1}\right)+\mathrm{SA}(0.25 \mathrm{mM})$, $\mathrm{T} 7=\mathrm{NaCl}\left(8 \mathrm{dSm}^{-1}\right)+T$. asperellum $\mathrm{T} 42, \mathrm{~T} 8$ $=\mathrm{NaCl}\left(8 \mathrm{dSm}^{-1}\right)+\mathrm{SA}(0.25 \mathrm{mM})+T$. asperellum $\mathrm{T} 42, \mathrm{~T} 9=\mathrm{NaCl}\left(12 \mathrm{dSm}^{-1}\right), \mathrm{T} 10=$ $\mathrm{NaCl}\left(12 \mathrm{dSm}^{-1}\right)+\mathrm{SA}(0.25 \mathrm{mM}), \mathrm{T} 11=\mathrm{NaCl}$ 
$\left(12 \mathrm{dSm}^{-1}\right)+T$. asperellum $\mathrm{T} 42, \mathrm{~T} 12=\mathrm{NaCl}$ $\left(12 \mathrm{dSm}^{-1}\right)+\mathrm{SA}(0.25 \mathrm{mM})+$ T. asperellum $\mathrm{T} 42$.

\section{Seed treatment}

Good, healthy looking and uniform seeds of pea variety 'HUP-2' were treated with the spore suspension of Trichoderma asperellum (T42) $\left(1 \times 10^{6}\right.$ spores $\left.\mathrm{ml}^{-1}\right)$ for 4 to $5 \mathrm{~h}$ and then used for sowing in pots. After germination, a population of five plants per pot was maintained. After 20 days of sowing, twelve pots were imposed with 40,80 and 120 $\mathrm{mM} \mathrm{NaCl}$ treatment, which produced 4,8 and $12 \mathrm{dSm}^{-1}$, respectively as measured by Electrical conductivity (EC) in order to maintain the required salinity levels in the pots at weekly intervals. In each salinity level, three pots were treated with SA $(0.25 \mathrm{mM}$ as foliar application), three with Trichoderma and three with both SA and Trichoderma combination, and similar number of pots were not given any salinity treatment and they served as control.

\section{Hydrogen peroxide}

Hydrogen peroxide was determined in first fully expanded leaf from the normal and stressed plants. The estimation was done as per the protocol of Mukherjee and Choudhary (1983).

Histochemical determination of $\mathrm{H}_{2} \mathrm{O}_{2}$ and $\mathrm{O}_{2}^{-}$in pea leaves

The histochemical staining of $\mathrm{H}_{2} \mathrm{O}_{2}$ and $\mathrm{O}_{2}{ }^{-}$ was performed as previously described by Jabs et al., (1996) and Thordal-Christensen et al., (1997), respectively, with some modification. In case of $\mathrm{H}_{2} \mathrm{O}_{2}$, different treated pea leaves were dipped in Diamino-benzidine $\left(1 \mathrm{mg} \mathrm{ml}^{-1}, \mathrm{pH} 3\right)$ and incubate for 6-8 $\mathrm{h}$ in dark at $25^{\circ} \mathrm{C}$. Dechlorophylization was performed by transferring leaf samples in bleaching solution [ethanol/acetic acid/glycerol $(3: 1: 1 ; \mathrm{v} / \mathrm{v})]$ and boiled in a water bath for $10-15 \mathrm{~min}$ at $90^{\circ} \mathrm{C}$. After that, leaves were briefly rinsed in distilled water twice.

However, in case of $\mathrm{O}_{2}{ }^{-}$, leaf samples were dipped in $0.2 \mathrm{mg} \mathrm{ml}^{-1} \mathrm{NBT}$ in $25 \mathrm{mM}$ HEPES buffer ( $\mathrm{pH} \mathrm{7.8)}$ and incubated at $25^{\circ} \mathrm{C}$ in the dark for $3 \mathrm{~h}$. Leaves were rinsed in $80 \%$ (v/v) ethanol for $15 \mathrm{~min}$ at $80^{\circ} \mathrm{C}$ and mounted in lactic acid/phenol/water $(1: 1: 1 ; \mathrm{v} / \mathrm{v})$, the developed staining on leaves were observed through microscope.

\section{Malondialdehyde (MDA) content}

MDA content was determined in fully expanded leaf from the top of the plants using $0.5 \%$ Thiobarbituric acid (TBA) in 20\% TCA. The level of lipid peroxidation was measured in terms of MDA content, a product of lipid peroxidation, according to the methods proposed by Hodges et al., (1999) and absorbance was recorded at $532 \mathrm{~nm}$. The value for non-specific absorption at $600 \mathrm{~nm}$ was subtracted. The MDA equivalent was calculated as follows:

MDA $[\mathrm{nmol} /(\mathrm{mL}$ fresh weight $)]=\left[\left(A_{532}-\right.\right.$ $\left.\left.A_{600}\right) / 155000\right] \times 10^{6}$

\section{Proline content}

Free Proline content in the leaves was determined by the method of Bates et al., (1973) using acid ninhydrin reagent. The reaction mixture containing (1:1:1) ratio of supernatant, glacial acetic acid and ninhydrin reagent was boiled at $100^{\circ} \mathrm{C}$ for $30 \mathrm{~min}$ till brick red colour developed. After cooling, proline content which indicate brick red colour was dissolved in toluene, then mixed well and the absorbance was read at $520 \mathrm{~nm}$ using spectrophotometer (Spectra Max M2 USA) against toluene blank. 


\section{Superoxide dismutase activity (SOD)}

SOD activity was estimated by the method as proposed by Dhindsa et al., (1981). Three $\mathrm{mL}$ of the reaction mixture containing $0.1 \mathrm{~mL}$ of $1.5 \mathrm{M}$ sodium carbonate, $0.2 \mathrm{~mL}$ of $200 \mathrm{mM}$ methionine, $0.1 \mathrm{~mL}$ of $2.25 \mathrm{mM}$ NBT, $0.1 \mathrm{~mL}$ of $3 \mathrm{mM}$ EDTA, $1.4 \mathrm{~mL}$ of $0.1 \mathrm{M}$ phosphate buffer, $1 \mathrm{~mL}$ of DW and $0.1 \mathrm{~mL}$ of enzyme extract were taken in test tubes in duplicate from each enzyme sample. Two tubes without enzyme extract were taken as control. The reaction was started by adding $0.1 \mathrm{~mL}$ riboflavin $(60 \mu \mathrm{M})$ and placing the tubes below a light source of two $15 \mathrm{~W}$ florescent lamps for $15 \mathrm{~min}$. Reaction was stopped by switching off the light and covering the tubes by black cloth. Tubes without enzyme extract developed maximum colour. Absorbance was recorded at $560 \mathrm{~nm}$ and SOD activity calculated as follows:

Enzyme* ${ }_{\text {light }}-\left(\right.$ Enzyme $_{\text {light }}^{\#}-$ Enzyme* $\left._{\text {dark }}\right)$ Enzyme Unit $(\mathrm{EU})=$ Enzyme* ${ }_{\text {light }} / 2$

$*=$ Without Enzyme.

\# = With Enzyme.

\section{Ascorbate peroxidase activity}

Ascorbate peroxidase activity was estimated in the first fully expanded leaf according to the method as proposed by Nakano and Asada (1980).

\section{Plant cell death assay}

Cell death was estimated as described by Levine et al., (1994). For each sample, a $400-\mu \mathrm{L}$ aliquot of cells was incubated with $0.05 \%$ Evans blue for $30 \mathrm{~min}$ and then washed extensively 4-5 times with distilled water. The dye bound to dead cells was solubilized in $50 \%$ methanol with $1 \%$ SDS for $30 \mathrm{~min}$ at $50^{\circ} \mathrm{C}$ and absorbance was recorded at $600 \mathrm{~nm}$.

\section{Data analysis}

All data were presented as mean values of three replicates and analyzed using a statistical package, SPSS (Version 16.0). One-way ANOVA (analysis of variance) was employed followed by Duncan's multiple range tests to determine the significant difference among means of the treatment at $P \leq 0.05$.

\section{Results and Discussion}

\section{Hydrogen peroxide content $\left(\mathrm{H}_{2} \mathrm{O}_{2}, \mu \mathrm{mol} \mathrm{g} \mathrm{g}^{-1}\right.$} fresh weight)

There was a significant increment in $\mathrm{H}_{2} \mathrm{O}_{2}$ content with increasing level of salinity (Fig. 1A). Among the salinity level, maximum 186.04\% $\mathrm{H}_{2} \mathrm{O}_{2}$ content was observed in $\mathrm{T} 9$ (86.29 $\mu \mathrm{mol} \mathrm{g} \mathrm{g}^{-1}$ fresh weight) followed by $127.30 \%$ in T5 $\left(68.57 \mu \mathrm{mol} \mathrm{g}^{-1}\right.$ fresh weight $)$ as compared to control T0 $\left(30.17 \mu \mathrm{mol} \mathrm{g}{ }^{-1}\right.$ fresh weight) at 80 DAS. SA and Trichoderma, alone or in combination, ameliorated salt stress induced responses at each salinity level as compared to respective salinity control. Among treatments, maximum $24.04 \%$ reduction in $\mathrm{H}_{2} \mathrm{O}_{2}$ content was recorded in T2 $\left(17.0 \mu \mathrm{mol} \mathrm{g}^{-1}\right.$ fresh weight) followed by $21.80 \%$ in $\mathrm{T} 4\left(17.50 \mu \mathrm{mol} \mathrm{g}{ }^{-1}\right.$ fresh weight) as compared to respective salinity control, T1 $\left(22.38 \mu \mathrm{mol} \mathrm{g} \mathrm{g}^{-1}\right.$ fresh weight) at 60 DAS under $4 \mathrm{dSm}^{-1}$ salinity level.

\section{Malondialdehyde (MDA) content (nM g ${ }^{-1}$ fresh weight)}

MDA content is the key indicator of salinity induced oxidative stress responses on plant cell membrane as a lipid peroxidation. There was a significant increase in MDA content with the increasing salinity levels $(4,8$ and 12 $\mathrm{dSm}^{-1}$; Fig. 1B). Among the salinity level, maximum 206.28\% MDA content was recorded in $\mathrm{T} 9\left(4.10 \mathrm{nM} \mathrm{g}^{-1}\right.$ fresh weigh) 
followed by $146.85 \%$ in $\mathrm{T} 5\left(3.31 \mathrm{nM} \mathrm{g}^{-1}\right.$ fresh weigh) as compared to control T0 (1.34 nM $\mathrm{g}^{-1}$ fresh weigh) at 40 DAS. Among treatments, SA and Trichoderma, applied alone or in combination, showed ameliorating effect on all the salinity levels by decreasing MDA content.

Among treatments, maximum 26.87\% reduction in MDA content was observed in T2 $\left(0.96 \mathrm{nM} \mathrm{g}^{-1}\right.$ fresh weigh) followed by $22.14 \%$ in $\mathrm{T} 6\left(1.28 \mathrm{nM} \mathrm{g}^{-1}\right.$ fresh weigh) as compared to respective salinity controls $\mathrm{T} 1\left(1.31 \mathrm{nM} \mathrm{g}^{-1}\right.$ fresh weigh) and T5 (1.64 $\mathrm{nM} \mathrm{g}^{-1}$ fresh weigh) respectively, at 60 DAS.

\section{Proline content ( $\mathrm{mg} \mathrm{g}^{-1}$ fresh weight)}

Plants increase osmoprotectant like proline, glycine-betaine under stressful environment significantly for maintaining their homeostasis. Among salinity level, maximum $802.77 \%$ proline content was recorded in $\mathrm{T} 9$ (5.04 $\mathrm{mg} \mathrm{g}^{-1}$ fresh weight) followed by $579.28 \%$ in $\mathrm{T} 5$ (3.79 $\mathrm{mg} \mathrm{g}^{-1}$ fresh weight) as compared to control T0 $\left(0.56 \mathrm{mg} \mathrm{g}^{-1}\right.$ fresh weight) at 80 DAS (Fig. 1C). Among treatments, maximum $42.94 \%$ reduction was observed in proline content in T10 $(2.87 \mathrm{mg}$ $\mathrm{g}^{-1}$ fresh weight) followed by $37.42 \%$ in T6 (2.37 mg g ${ }^{-1}$ fresh weight) as compared to respective salinity controls $\mathrm{T} 9\left(5.04 \mathrm{mg} \mathrm{g}^{-1}\right.$ fresh weight) and $\mathrm{T} 5$ (3.79 $\mathrm{mg} \mathrm{g}^{-1}$ fresh weight), respectively at $80 \mathrm{DAS}$, although the maximum proline content $\left(6.63 \mathrm{mg} \mathrm{g}^{-1}\right.$ fresh weight) was recorded at 60 DAS in $12 \mathrm{dSm}^{-1}$ level of salinity.

Superoxide dismutase activity (SOD, $\mathrm{U} \mathrm{g}^{-1}$ fresh weight $\min ^{-1}$ )

The data on superoxide dismutase (SOD) activity at different treatments under salinity stress showed a significant decrease in SOD activity with the increasing salinity levels (Fig. 1D). Maximum $94.83 \%$ SOD activity was recorded in $\mathrm{T} 5\left(1.13 \mathrm{U} \mathrm{g}^{-1}\right.$ fresh weight $\left.\min ^{-1}\right)$ followed by $85.05 \%$ in $\mathrm{T} 1\left(1.07 \mathrm{U} \mathrm{g}^{-1}\right.$ fresh weight $\mathrm{min}^{-1}$ ) as compared to control T0 $\left(0.58 \mathrm{U} \mathrm{g}^{-1}\right.$ fresh weight $\left.\mathrm{min}^{-1}\right)$ at $40 \mathrm{DAS}$. Among treatments, salicylic acid and Trichoderma showed ameliorating effect on all the salinity levels through activation of antioxidative system. The treatment with Trichoderma recorded maximum $128.94 \%$ SOD activity in T11 $\left(0.87 \mathrm{U} \mathrm{g}^{-1}\right.$ fresh weight $\min ^{-1}$ ) followed by $126.31 \%$ in combined treatment of salicylic acid and Trichoderma $\mathrm{T} 12\left(0.86 \mathrm{U} \mathrm{g} \mathrm{g}^{-1}\right.$ fresh weight $\left.\mathrm{min}^{-1}\right)$ as compared to respective salinity control T9 $\left(0.38 \mathrm{U} \mathrm{g}^{-1}\right.$ fresh weight $\left.\mathrm{min}^{-1}\right)$ at $60 \mathrm{DAS}$. Maximum SOD activity was recorded in T4 $\left(1.42 \mathrm{U} \mathrm{g}^{-1}\right.$ fresh weight $\left.\mathrm{min}^{-1}\right)$ at $4 \mathrm{dSm}^{-1}$ salinity level.

Ascorbate Peroxidase Activity (APX, U $\mathbf{g}^{-1}$ fresh weight min $^{-1}$ )

Data pertaining to APX activity are presented in Figure 1E under different salinity levels (4, 8 and $12 \mathrm{dSm}^{-1}$ ), which elucidate that there was a significant increment on APX activity with increasing level of salinity upto $8 \mathrm{dSm}^{-1}$ but thereafter it declined. Among salinity levels, maximum $272.2 \%$ APX activity was recorded in T5 $\left(0.67 \mathrm{U} \mathrm{g}^{-1}\right.$ fresh weight $\left.\mathrm{min}^{-1}\right)$ followed by $187.03 \%$ in $\mathrm{T} 9\left(0.52 \mathrm{U} \mathrm{g}^{-1}\right.$ fresh weight $\left.\mathrm{min}^{-1}\right)$ as compared to control T0 (0.18 $\mathrm{U} \mathrm{g}^{-1}$ fresh weight $\mathrm{min}^{-1}$ ) at 40 DAS. SA and Trichoderma, applied alone or in combination, showed increasing APX activity with increased salinity level i.e. 4,8 and $12 \mathrm{dSm}^{-1}$ as compared to control of respective salinity level.

Among treatments, maximum $63.41 \%$ APX activity was recorded with treatment SA in T10 (0.67 $\mathrm{U} \mathrm{g} \mathrm{g}^{-1}$ fresh weight $\mathrm{min}^{-1}$ ) followed by $53.65 \%$ in combined treatment of SA and Trichoderma, in T12 $\left(0.63 \mathrm{U} \mathrm{g}^{-1}\right.$ fresh weight $\min ^{-1}$ ) as compared to respective salinity control T9 $\left(0.41 \mathrm{U} \mathrm{g}^{-1}\right.$ fresh weight $\left.\mathrm{min}^{-1}\right)$ at 40 DAS in $12 \mathrm{dSm}^{-1}$ salinity level. 
Fig.1 A-F Effect of salicylic acid and Trichoderma asperellum T42 on hydrogen peroxide content (A), malondialdehyde content (B), Proline content (C), Superoxide dismutase activity

(D), ascorbate peroxidase activity (E) and Plant cell death (F) on pea (Pisum sativum L.) genotype HUP-2 under different concentrations of salinity stress $\left(4,8\right.$ and $\left.12 \mathrm{dSm}^{-1}\right)$. T0 $=$ Control, $\mathrm{T} 1=\mathrm{NaCl}\left(4 \mathrm{dSm}^{-1}\right), \mathrm{T} 2=\mathrm{NaCl}\left(4 \mathrm{dSm}^{-1}\right)+\mathrm{SA}(0.25 \mathrm{mM}), \mathrm{T} 3=\mathrm{NaCl}\left(4 \mathrm{dSm}^{-1}\right)+T$. asperellum $\mathrm{T} 42, \mathrm{~T} 4=\mathrm{NaCl}\left(4 \mathrm{dSm}^{-1}\right)+\mathrm{SA}(0.25 \mathrm{mM})+T$. asperellum $\mathrm{T} 42, \mathrm{~T} 5=\mathrm{NaCl}(8 \mathrm{dSm}$ $\left.{ }^{1}\right), \mathrm{T} 6=\mathrm{NaCl}\left(8 \mathrm{dSm}^{-1}\right)+\mathrm{SA}(0.25 \mathrm{mM}), \mathrm{T} 7=\mathrm{NaCl}\left(8 \mathrm{dSm}^{-1}\right)+T$. asperellum $\mathrm{T} 42, \mathrm{~T} 8=\mathrm{NaCl}$ $\left(8 \mathrm{dSm}^{-1}\right)+\mathrm{SA}(0.25 \mathrm{mM})+T$. asperellum $\mathrm{T} 42, \mathrm{~T} 9=\mathrm{NaCl}\left(12 \mathrm{dSm}^{-1}\right), \mathrm{T} 10=\mathrm{NaCl}\left(12 \mathrm{dSm}^{-1}\right)$

$+\mathrm{SA}(0.25 \mathrm{mM}), \mathrm{T} 11=\mathrm{NaCl}\left(12 \mathrm{dSm}^{-1}\right)+$ T. asperellum $\mathrm{T} 42, \mathrm{~T} 12=\mathrm{NaCl}\left(12 \mathrm{dSm}^{-1}\right)+\mathrm{SA}$

$(0.25 \mathrm{mM})+T$. asperellum $\mathrm{T} 42$. Data $(\mathrm{T} 0$ to $\mathrm{T} 12)$ are in the form of mean $\pm \mathrm{SEM}$, and means followed by the same letters within the columns are not significantly different at $P \leq 0.05$ using

Duncan's multiple range test

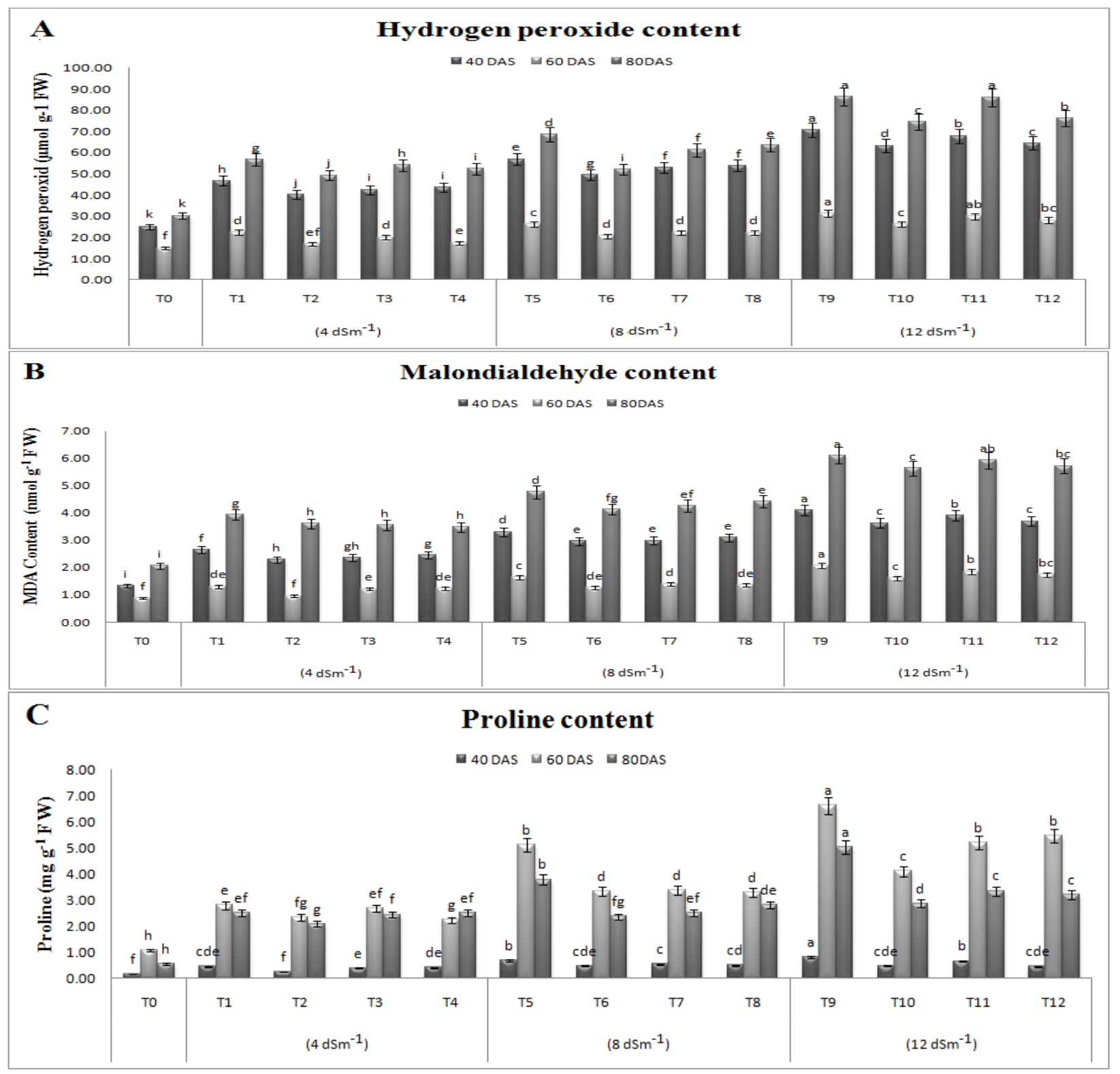




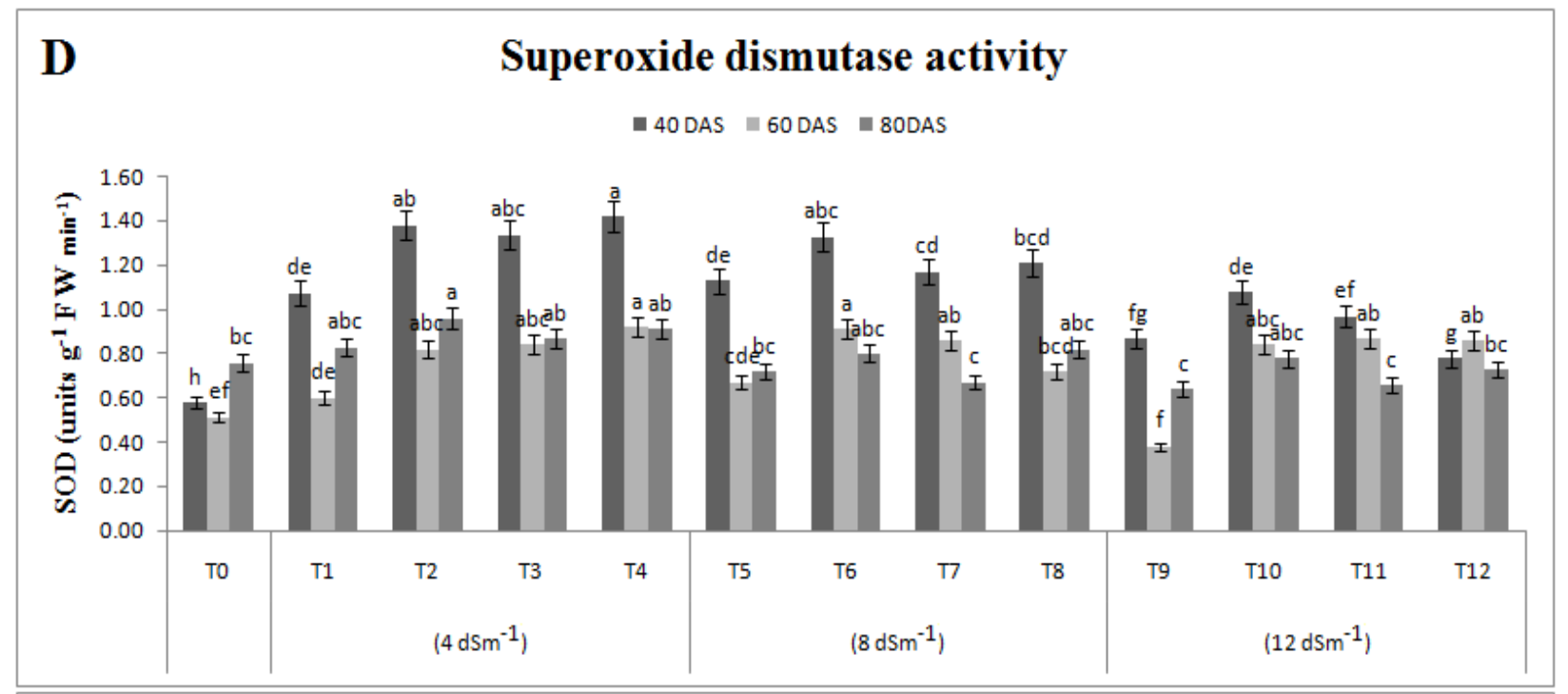

E Ascorbate Peroxidase activity

U0DAS $\square$ GODAS $\square$ 80DAS

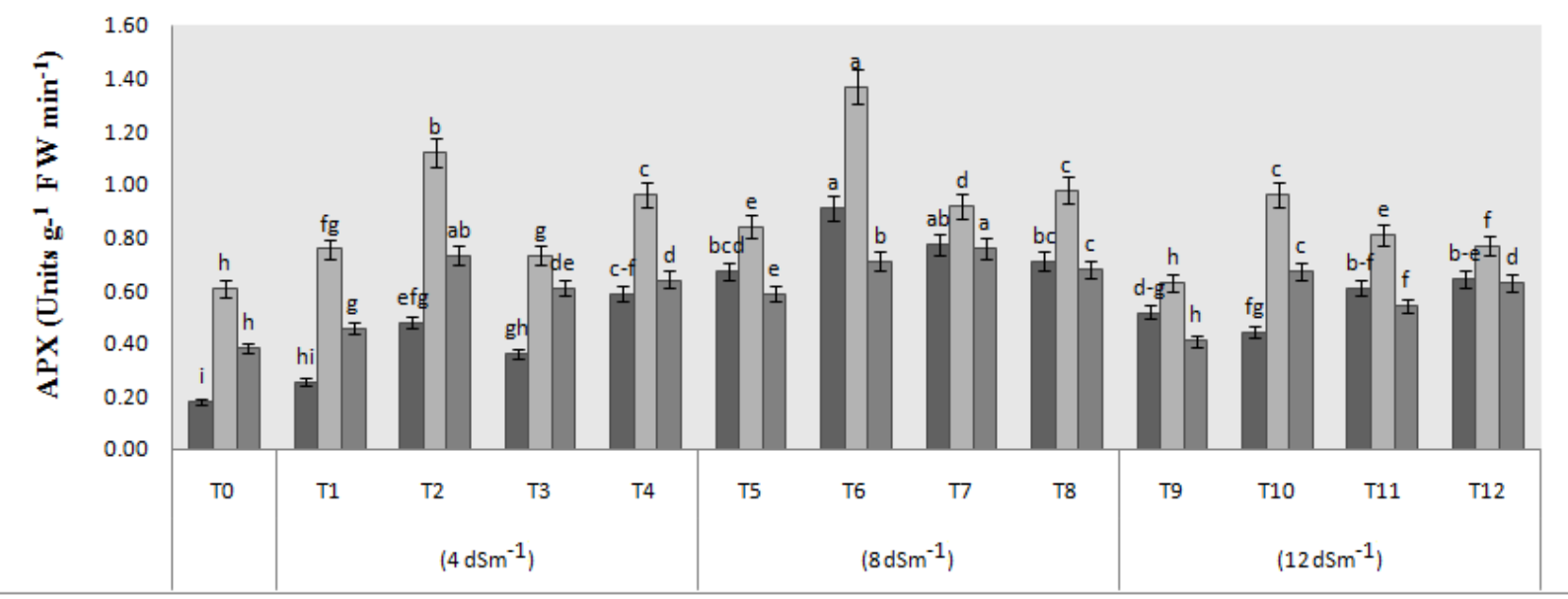

\section{F Plant cell death}

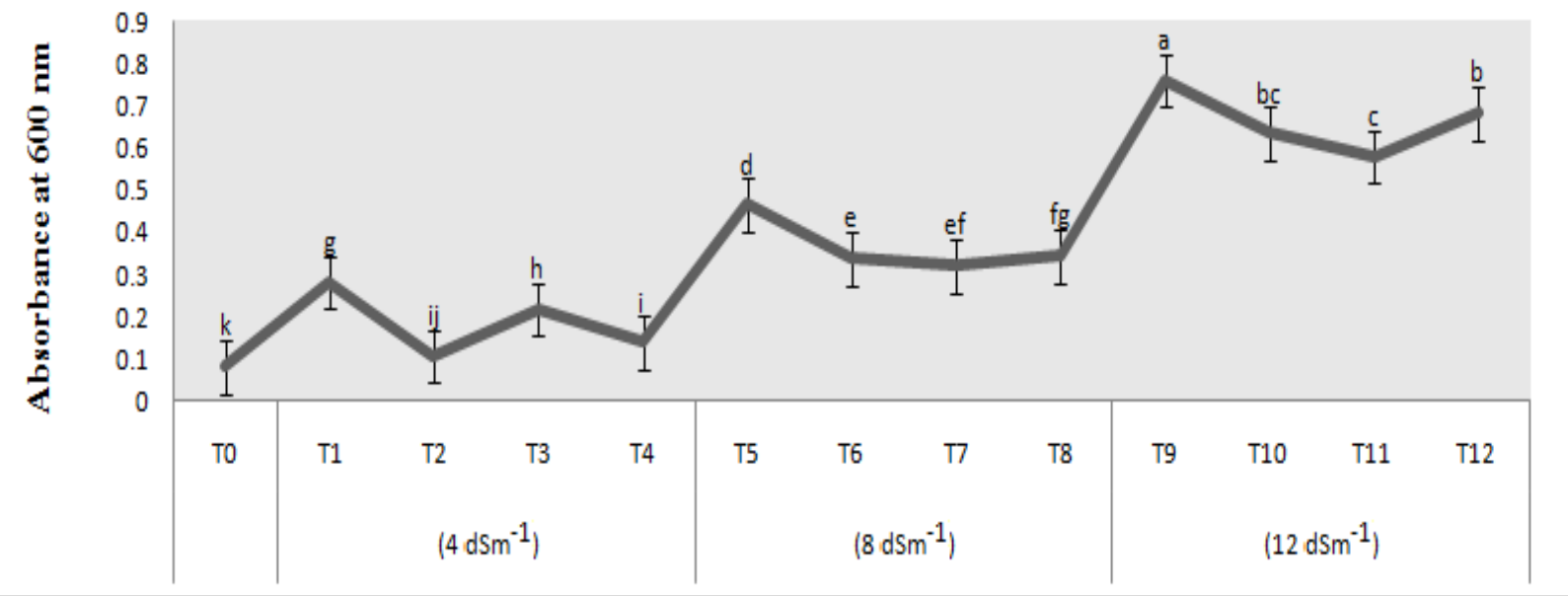


Fig.2 Effect of salicylic acid (SA) and Trichoderma asperellum T42 (T) in pea under different concentrations of salinity stress $\left(4,8\right.$ and $12 \mathrm{dSm}^{-1}$ ). Detection of $\mathrm{H}_{2} \mathrm{O}_{2}$ (Left), in different treatments of pea leaves was performed using a solution of 3,3-diaminobenzidine (DAB) which binds with $\mathrm{H}_{2} \mathrm{O}_{2}$ and visualized as a reddish-brown in colour. Prior to imaging, chlorophyll was removed from leaves with $70 \%$ (v/v) ethanol. However, in case of superoxide radical (Right) leaves were floated in NBT in $25 \mathrm{mM}$ HEPES buffer ( $\mathrm{pH} 7.8$ ), $0.2 \mathrm{mg} \mathrm{ml}^{-1}$ nitroblue tetrazolium (NBT) in which superoxide radical $\left(\mathrm{O}_{2}{ }^{\bullet-}\right)$ produced more in high salinity level as compared to control and these $\mathrm{O}_{2} \bullet$ - radicals react with NBT to produce a dark blue insoluble formazan compound on leaf surface. In both the cases, observed histochemically that formation of $\mathrm{H}_{2} \mathrm{O}_{2}$ and $\mathrm{O}_{2} \bullet$ - increases with increasing the concentrations of salinity stress as compared to control (without impose salinity) but these responses were ameliorated by application of SA and Trichoderma asperellum T42, either alone or in combination, as compared to respective salinity controls at each salinity level

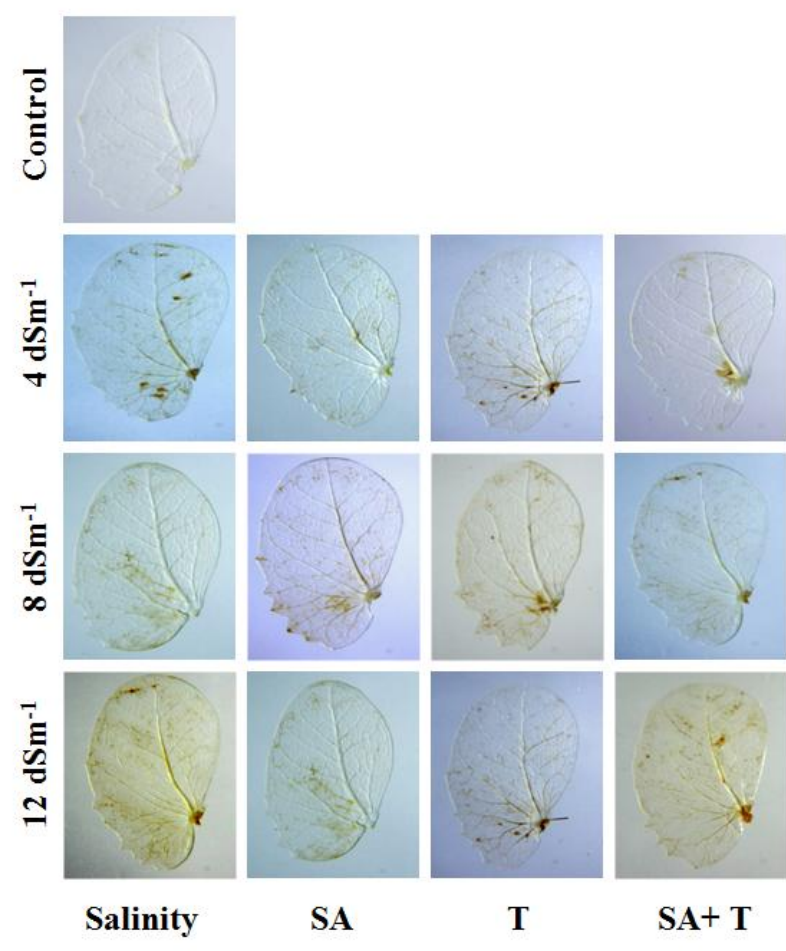

\section{Plant cell death}

Observations related to plant cell death are presented in Figure $1 \mathrm{~F}$ and expressed in absorbance $\left(\mathrm{A}_{600}\right)$. The responses of SA and Trichoderma used either alone or in combination were determined in pea under different concentrations of salt stresses $(4,8$ and $\left.12 \mathrm{dSm}^{-1}\right)$. Data among salinity levels, maximum $825.61 \%$ absorbance was recorded in T9 (0.759 at $\left.\mathrm{A}_{600}\right)$ followed by $467.07 \%$ in

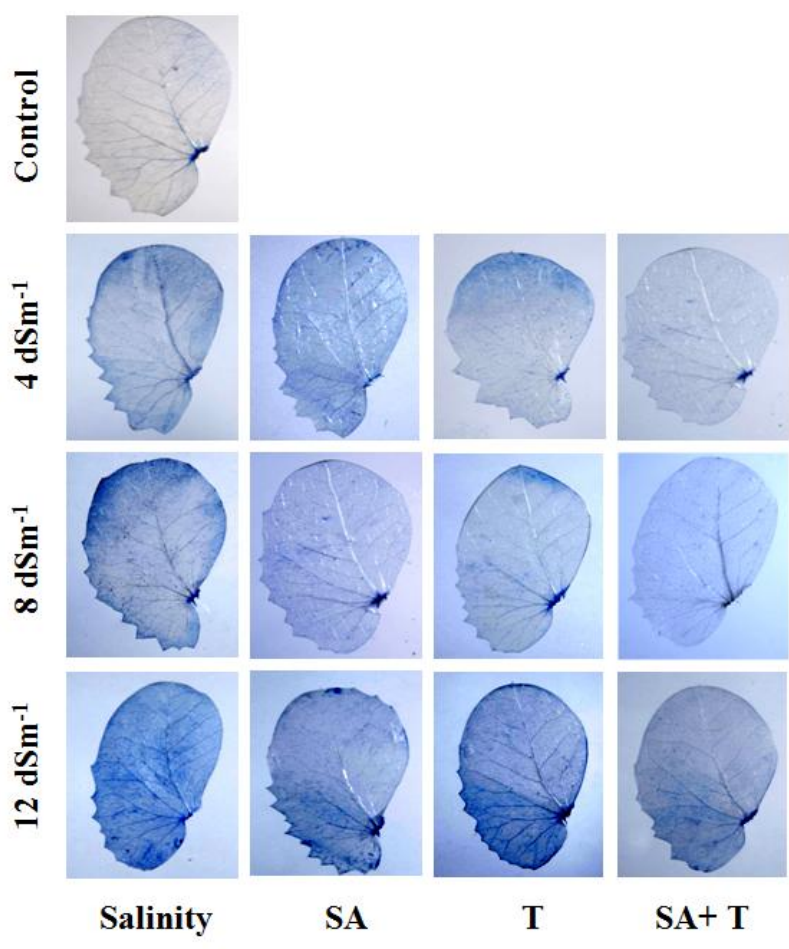

T5 (0.465 at $\left.\mathrm{A}_{600}\right)$ as compared to control T0 $\left(0.082\right.$ at $\left.\mathrm{A}_{600}\right)$ which indicated for increased plant cell death with increasing absorbance $\left(\mathrm{A}_{600}\right)$. SA and Trichoderma showed ameliorating effect at each salinity level. Among treatments, maximum $62.19 \%$ reduction in plant cell death was observed in $\mathrm{T} 2\left(0.107\right.$ at $\left.\mathrm{A}_{600}\right)$ followed by $51.23 \%$ in $\mathrm{T} 4$ (0.138 at $\left.\mathrm{A}_{600}\right)$ as compared to respective salinity control $\mathrm{T} 1\left(0.283\right.$ at $\left.\mathrm{A}_{600}\right)$ under 4 $\mathrm{dSm}^{-1}$ salinity level. 
Salinity stress is an important and serious environmental threat that is highly associated with drought stress. It is uniform and continues process that can be developed by both natural and human intervention. Soil salinization occurs naturally either where parent material is rich in soluble salts or in arid and semiarid regions where rainfall is insufficient due to climate change. In these areas, there is leaching out of the salts in upper most layer of fertile soil by the process of evapo-transpiration resulting in formation of salt affected soil. Salinization also occurs by salty irrigation or faulty irrigation practices where proper drainage does not exist for leaching and removal of salts making soil salty and unproductive (Azarmi et al., 2016, Mazhar et al., 2016 and Pourbabaee et al., 2016).

Plant cell membrane is damaged due to increase in ion concentration which results in increase in reactive oxygen species (ROS) like superoxide radical $\left(\mathrm{O}_{2}^{-{ }^{-}}\right)$and hydrogen peroxide $\left(\mathrm{H}_{2} \mathrm{O}_{2}\right)$ that lead to reduction in chlorophyll content and increase in lipid peroxidation i.e. MDA content and plant cell death, that disturb the cell integrity and negatively affect plant growth and development. Similar finding was reported by Khan et al., (2013) in cucumber, Hashem et al., (2016) in Acacia gerrardii, Habib et al., (2016) in okara and Sharifi et al., (2017) in wheat. Plants treated with SA and Trichoderma showed significant decrease in $\mathrm{O}_{2}{ }^{--}, \mathrm{H}_{2} \mathrm{O}_{2}$, MDA content, plant cell death and increase in chlorophyll content as compared to respective salinity controls $(4,8$ and 12 $\left.\mathrm{dSm}^{-1}\right)$. This is supported by other studies (Kumara et al., 2010; Rawat et al., 2011; Enteshari and Sharifian, 2012; Weizhen and Lei, 2013; Zhang et al., 2016).

Reactive oxygen species such as superoxide radical and $\mathrm{H}_{2} \mathrm{O}_{2}$ content were significantly increased with increase in $\mathrm{NaCl}$ concentration in the present study (Singh and Jha, 2016; Hashem et al., 2016). These were found to decrease with application of SA and Trichoderma under salt stress situation by activation of different antioxidative enzymes i.e., SOD and APX under salinity stress. Lipid peroxidation in plant was assessed by MDA content which is a more reliable indicator of salt stress tolerance. In the present study, there was an increase in MDA content under salinity stress as compared to control. This finding is supported by Khan et al., (2013), Ahmad et al., (2016) and Azarmi et al., (2016). The MDA content is produced by the decomposition of polyunsaturated fatty acids during peroxidation of membrane lipids under salinity stress. It is used as biomarker for lipid peroxidation. The MDA content was significantly decreased with application of SA and Trichoderma, when used singly or in combination, under salinity stress.

Water is an important component in cellular structure and has a significant role in metabolic processes in plant. Salinity stress is not a problem of water scarcity but ion concentration that damages plant cell membrane. Plants have inherent capacity to protect their physiological function through production of osmoprotectants i.e. proline content under stress environment. It is an important component which contributes to reduction of injurious effects of stress factors and accelerates the restoration processes (Manchanda and Garg, 2011; Saghafi et al., 2013; Koc et al., 2016; Abo-Kora, 2016). It increased with application of SA and Trichoderma, when applied singly or in combination, as compared to respective salinity stress in the present study. SOD and APX are important antioxidative enzymes which reduce the responses of salt-induced ROS. Their activity increased significantly with increase in salinity, at low level. The SOD and APX activity were increased with application of SA and Trichoderma; SOD 
converts reactive oxygen species superoxide radical $\left(\mathrm{O}_{2}{ }^{-}\right)$to $\mathrm{H}_{2} \mathrm{O}_{2}$, and the conversion of $\mathrm{H}_{2} \mathrm{O}_{2}$ to $\mathrm{H}_{2} \mathrm{O}$ and $\mathrm{O}_{2}$ is felicitated by APX in the presence of ascorbic acid (Lee et al., 2001; Mandhania et al., 2006; Chutipaijit et al., 2009; Kumara et al., 2010; Barakat, 2011; Weizhen and Lei, 2013).

Salinity is considered a significant factor affecting crop production and agricultural sustainability. It significantly increases most of the parameters confirmed as $\mathrm{O}_{2}{ }^{-}, \mathrm{H}_{2} \mathrm{O}_{2}$, MDA content, plant cell death and decreases SOD and APX activity which directly influences the plant growth and development. Exogenous applications of SA $(0.25 \mathrm{mM})$ and Trichoderma asperellum $\mathrm{T} 42$ in single and combined treatments, ameliorated the effect of salt stress by improving salt tolerance capacity of plant in various parameters studied. The application of SA in treatments (T2, T6 and T10) and Trichoderma asperellum $\mathrm{T} 42$ (T3, T7 and T11), singly or in combination (T4, T8 and T12) showed best results under each salinity level as compared to respective salinity controls (T1, T5 and T9) and mitigated salt induced oxidative stress in pea plants by modulating anti-oxidant defense system. Trichoderma showed positive response up to $8 \mathrm{dSm}^{-1}$ level of salinity stress.

\section{References}

Abo-Kora, H.A. (2016). Endophytic colonization of maize (Zea mays v.) root plants by PGPRs under salinity stress. Nat. Sci. 14(7): 34-51.

Ahmad, P., Latef Arafat, A.A., Hashem, A., Abd_Allah, E.F., Gucel, S and Tran, L.S.P. (2016). Nitric oxide mitigates salt stress by regulating levels of osmolytes and antioxidant enzymes in chickpea. Front. Plant Sci. 7(347): 1-11.

Arnon, D.I. (1949). Copper enzymes in isolated chloroplast, polyphenol oxidase. Plant Physiol. 24:1-15.
Azarmi, F., Mozaffari, V., Hamidpour, M and Abbaszadeh-Dahaji, P. (2016). Interactive effect of fluorescent Pseudomonads rhizobacteria and $\mathrm{Zn}$ on the Growth, Chemical composition and water relations of Pistachio (Pistacia vera L.) seedling under $\mathrm{NaCl}$ stress. Commun. Soil Sci. Plant Anal. 47(8): 955-972.

Barakat, N.A.M. (2011). Oxidative stress markers and antioxidant potential of wheat treated with phytohormones under salinity stress. J. Stress Physiol. Biochem. 7(4): 250-267.

Bastam, N., Baninasab, B and Ghobadi, C. (2013). Improving salt tolerance by exogenous application of salicylic acid in seedlings of pistachio. Plant Growth Regul. 69: 275-284.

Bates, L.S., Waldeen, R.P and Teale, I.D. (1973). Rapid determination of free proline for water stress studies. Plant Cell. 39: 205-208.

Chutipaijit, S., Cha-Um, S and Sompornpail, K. (2009). Different accumulation of proline and flavonoid in indica Rice variete against salinity. Pak. J. Bot. 41: 2497-2506.

Dhindsa, R.S., Plumb-Dhindsa, P and Thorpe, T.A. (1981). Leaf senescence: correlated with increased levels of membrane permeability and lipid peroxidation, and decreased levels of superoxide dismutase and catalase. J. Exp. Bot. 32: 93-101.

Elzebroek, T and Wind, K. (2008). Guide to cultivated plants. CAB International, Oxford shire, UK.

Enteshari, S and Sharifian, S. (2012). Influence of salicylic acid on growth and some biochemical parameters in a C4 plant (Panicum miliaceum L.) under saline conditions. Afri. J. Biotech. 11(3): 621-627.

Flowers, T.J., Gaur, P.M., Gowda, C.L., Krishnamurthy, L., Samineni, $\mathrm{S}$ and 
Siddique, K.M. (2010). Salt sensitivity in chickpea. Plant Cell Environ. 33: 490-509.

Food and Agriculture Organization (2011). Rome.

Gautam, S and Singh, P.K. (2009). Salicylic acid induced salinity tolerance in corn grown under $\mathrm{NaCl}$ stress. Acta Physiol. Plant. 31: 1185-1190.

Habib, S.H., Kausarm $\mathrm{H}$ and Saud, H.M. (2016). Plant growth promoting rhizobacteria enhance salinity stress tolerance in okra through ROSScavenging enzymes. BioMed Res. Int. 6284547: 1-10.

Harman, G.E and Kubicek, C.P. (eds.) (1998). Trichoderma and Gliocladium (Vol.2).Taylor and Francis Ltd. U.K.

Hartmann, H.T., Kofranekm, A.M., Rubatzky, V.E and Flocker, W.J. (1988). Plant science: Growth, development and utilization of cultivated plants. 2nd ed. Prentice Hall Career and Technology. Englewood Cliffs NJ.

Hashem, A., Abd_Allah, E.F., Alqarawi, A.A., Al-Huqail, A.A and Shah, M.A. (2016). Induction of osmoregulation and modulation of salt stress in Acacia gerrardii Benth. by Arbuscular Mycorrhizal fungi and Bacillus subtilis (BERA 71). BioMed Res. Int. 6294098: 1-11.

Hermosa, R., Viterbo, A., Chet, I and Monte, E. (2012). Plant-beneficial effects of Trichoderma and of its genes. Microbiol. 158:17-25.

Hodges, D.M., DeLong, J.M., Forney, C.F and Prange, R.K. (1999). Improving the Thiobarbituric Acid-ReactiveSubstances Assay for Estimating Lipid Peroxidation in Plant Tissues Containing Anthocyanin and Other Interfering Compounds. Planta, 207: 604-611.

Howell, C.R. (2003). Mechanisms employed by Trichoderma species in the biological control of plant diseases: the history and evolution of current concepts. Plant Dis. 87:4-10.

Khan, M.M., Al-Masoudi, R.S.M., Al-Said, F and Khan, I. (2013). Salinity effects on Growth, Electrolyte leakage, Chlorophyll content and Lipid Peroxidation in Cucumber (Cucummis sativus L.). Int. Conf. Food Agril. Sci. 55: $1-5$.

Koc, A., Balci, G., Erturk, Y., Keles, H., Bakoglu, N and Ercisli, S. (2016). Influence of arbuscular mycorrhizae and plant growth promoting rhizobacteria on proline content, membrane permeability and growth of strawberry (Fragaria $\mathrm{x}$ ananassa Duch.) under salt stress. J. Appl Bot. food Qual. 89: 89-97.

Kumara, G.D.K., Ping, X.Y., Jun, Z.Z., Basnayake, B.M.V.S and Beneragama, C.K. (2010). Effects of exogenous salicylic acid on antioxidative enzyme activities and physiological characteristics in gerbera (Gerbera jamesonii L.) grown under $\mathrm{NaCl}$ stress. Journal of Zhejiang University Agric. Life Sci. 36(6): 591-601.

Lee, D.H., Kim, Y.S and Lee, C.B. (2001). The inductive responses of the antioxidant enzymes by salt stress in the rice (Oryza sativa L.). J. Plant Phyiol. 158: 737-745.

Levine, A., Tenhaken, R., Dixon, $\mathrm{R}$ and Lamb, C. (1994). $\mathrm{H}_{2} \mathrm{O}_{2}$ from the oxidative burst orchestrates the plant hypersensitive disease resistance response. Cell, 79: 583-593.

Liu, S., Dong, Y., Xu, L and Kong, J. (2014). Effects of foliar applications of nitric oxide and salicylic acid on salt induced changes in photosynthesis and antioxidative metabolism of cotton seedlings. Plant Growth Regul. 73: 6778.

Manchanda, G and Garg, N. (2011). Alleviation of salt-induced ionic, 
osmotic and oxidative stresses in Cajanus cajan nodules by AM inoculation. Plant Biosyst. 145(1): 8897.

Mandhania, S., Madan, S and Sawhney, V. (2006). Antioxidant defense mechanism under salt stress in wheat seedlings. Biol. Plant. 50: 227-231.

Mazhar, R., Ilyas, N., Saeed, M., Bibi, F and Batool, N. (2016). Biocontrol and salinity tolerance potential of Azospirillum lipoferum and its inoculation effect in wheat crop. Int. J. Agric. Biol. 18(3): 1-7.

Mukherjee, S.P and Choudhury, M.A. (1983). Implication of water stress induced changes in the levels of endogenous ascorbic acid and hydrogen peroxide in Vigna seedlings. Physiol. Plant. 58:166 -171 .

Nakano, Y and Asada, K. (1980). Spinach chloroplast scavenging hydrogen peroxide on illumination. Plant Cell Physiol. 21: 1295-1307.

Nutrition Facts: Peas (2015) http://vegonline. org/vegetable-nutrition-facts/nutritionfacts-peas.

Pourbabaee, A.A., Bahmani, E., Alikhani, H.A and Emami, S. (2016). Promotion of wheat growth under salt stress by holotolerant bacteria containing ACC deaminase. J. Agric. Sci. Tech. 18: 855864.

Qadir, M., Tubeileh, A., Akhtar, J., Larbi, A., Minhas, P.S and Khan, M.A. (2008). Productivity enhancement of saltaffected environments through crop diversification. Land Degrad. Dev. 19: 429-453.

Rawat, L., Singh, Y., Shukla, N and Kumar, J. (2011). Alleviation of the adverse effects of salinity stress in wheat (Triticum aestivum L.) by seed biopriming with salinity tolerant isolates of Trichoderma harzianum. Plant Soil. 347(1-2):387-400.
Saghafi, K., Ahmad, J., Asgharzadeh, A and Bakhtiari, S. (2013). The effect of microbial inoculants on physiological responces of two wheat cultivars under salt stress. Int. J. Adv. Biol. Biom. Res. 1(4): 421-431.

Sharifi, R.S., Khalilzadeh, R., Jalilian, J. (2017). Effects of biofertilizers and cycocel on some physiological and biochemical traits of wheat (Triticum aestivum L.) under salinity stress. Arch. Agron. Soil Sci. 63(3): 308-318.

Sharma, P., Jha, A.B., Dubey, R.S and Pessarakli, M. (2012). Reactive oxygen species, oxidative damage, and antioxidative defense mechanism in plants under stressful conditions. J. Bot. 2012: 217037.

Shoresh, M., Harman, G.E and Mastouri, F. (2010). Induced systemic resistance and plant responses to fungal biocontrol agents. Annu. Rev. Phytopathol. 48: 21-43.

Simaei, M., Khavarinejad, R.A., Saadatmand, S., Bernard, F and Fahimi, H. (2011). Interactive effects of salicylic acid and nitric oxide on soybean plants under $\mathrm{NaCl}$ salinity. Russ. J. Plant Physiol. 58: 783-790.

Singh, R.P and Jha, P.N. (2016). The multifarious PGPR Serratia marcescens CDP-13 augments induced systemic resistance and enhanced salinity tolerance of wheat (Triticum aestivum L.). PloS one. 11(6): 1-24.

Syeed, S., Anjum, N.A., Nazar, R., Iqbal, N., Masood, A and Khan, N.A. (2011). Salicylic acid mediated changes in photosynthesis, nutrients content and antioxidant metabolism in two mustard (Brassica juncea L.) cultivars differing in salt tolerance. Acta Physiol. Plant. 33: 877-886.

Tejera, N.A., Iribarne, C., Palma, F and Lluch, C. (2007). Inhibition of the catalase activity from Phaseolus 
vulgaris and Medicagosativa by sodium chloride. Plant Physiol. Biochem. 45: 535-541.

Thordal-Christensen, H., Zhang, Z., Wei, Y and Collinge, D.B. (1997). Subcellular localization of $\mathrm{H}_{2} \mathrm{O}_{2}$ in plants. $\mathrm{H}_{2} \mathrm{O}_{2}$ accumulation in papillae and hypersensitive response during the barley-powdery mildew interaction. Plant J. 11: 1187-1194.

Weizhen, Q and Lei, Z. (2013). Study of the siderophore-producing Trichoderma harzianum Q1 on cucumber growth promotion under salt stress. J. Basic Microbiol. 53:355-364.
Ying, Y., Yue, Y., Huang, X., Wang, H., Mei, L., Yu, W., Zheng, B and Wu, J. (2013). Salicylic acid induces physiological and biochemical changes in three red bayberry (Myric rubra) genotypes under water stress. Plant Growth Regul. 71: 181-189.

Zhang, S., Gan, Y and Xu, B. (2016). Application of Plant Growth Promoting Fungi Trichoderma longibrachiatum T6 enhances tolerance of wheat to salt stress through improvement of Antioxidative defense system and gene expression. Front. Plant Sci. 7 (1405): $1-11$.

\section{How to cite this article:}

Ajay Kumar Singh and Padmanabh Dwivedi. 2018. Modulation of Salt Stress Induced Responses in Pea (Pisum sativum L.) Through Salicylic Acid and Trichoderma Application. Int.J.Curr.Microbiol.App.Sci. 7(04): 3173-3185. doi: https://doi.org/10.20546/ijcmas.2018.704.360 